\title{
The transformative potential of counter accounts: a case study of animal rights activism
}

\author{
Matias Laine* \\ University of Tampere \\ $\&$ \\ Eija Vinnari \\ University of Tampere
}

"Accepted author manuscript" version (postprint),

Laine, M . \& Vinnari, E. (2017) "The transformative potential of counter accounts: a case study of animal rights activism", Accounting, Auditing \& Accountability Journal, Vol. 30 Issue: 7, pp. 1481-1510,

Publisher DOI: https://doi.org/10.1108/AAAJ-12-2015-2324

* corresponding author: matias.laine@tuni.fi

\section{Acknowledgments:}

The authors wish to thank the Guest Editors and the anonymous Reviewers for helpful comments. Prior versions of this paper have been presented at the departmental seminars of Turku School of Economics, Bangor University, Universidad Pablo de Olavide de Sevilla, and ESSEC Business School, the Ecological Accounts workshop in St. Andrews as well as the 27th International Congress on Social and Environmental Accounting Research. The feedback received from the audience at these events is also gratefully acknowledged. 


\title{
The transformative potential of counter accounts: a case study of animal rights activism
}

\begin{abstract}
Purpose: This paper analyses the dynamics and transformative potential associated with counter accounts. It explores how counter-accountants' attempts to rearticulate animal production result in their own identity becoming constructed during the conflict setting and how this identity subsequently relates to the transformative potential of the counter accounts.
\end{abstract}

Design/methodology/ approach: The paper investigates counter accounts released during an animal rights activists' campaign against industrial meat and dairy production in Finland. The counter accounts, consisting of secretly filmed videos from pig farms, contrasted the official depiction of animal farming and received wide publicity over several years. The main empirical dataset consists of 21 interviews with a variety of parties that have a stake in the conflict. This dataset is supplemented with a broad set of published documentary material.

Findings: The authors find that the counter accounts managed, to some extent, to rearticulate the meaning of animal production, potentially resulting in the emergence of small-scale societal effects. When trying to undermine the counter-accountants' radical political demand, the dominant social groups not only dismissed the counter accounts but also attempted to constitute the counter-accountants' identity as irresponsible, militant and negligent, drawing a firm political boundary between 'them' and 'us'. Likewise, the counteraccountants seemed reluctant to communicate with representatives of the dominant regime, resulting in an antagonistic as opposed to an agonistic relationship between the two political groups. The paper also discusses ethical questions concerning the production of counter accounts, the importance of having a clearly articulated political vision, and the challenges related to evaluating whether the counter accounts have been successful.

Originality/value: The paper provides insights into the design, use and reception of counter accounts in a real-life social setting, thus providing a direct response to a recent call by Thomson, Dey and Russell (2015). The paper illustrates the usefulness of the conceptual dynamic conflict arena framework presented by Thomson and colleagues (2015), and makes use of discourse theory (Laclau and M ouffe, 1985; Laclau, 2005, $2001,1996)$ to highlight how in exploring the transformative potential of counter accounts it is necessary to also consider how the identity of the counter-accountants becomes constructed and understood. Furthermore, the paper also seeks to advance the connections between accounting research and significant global problems by investigating an ethically and environmentally disputed industry, and by engaging with the interrelationships between accounts and accountability in the context of socio-ecological change.

Keywords: counter accounts; animal rights, animal welfare; discourse theory 


\section{The transformative potential of counter accounts: a case study of animal rights activism}

\section{Introduction}

Social and environmental accounting (SEA) research has displayed a persistent interest in forms of accounting that could support a transition towards a more democratic and sustainable world (e.g. Bebbington and Larrinaga, 2014; Gray, 2002). As corporate social and environmental accounts have often been noted to be self-serving and biased (Boiral, 2013; Cho et al., 2015; Milne et al., 2009), counter accounts ${ }^{1}$ produced by external parties have been suggested as an alternative to enhance information flow to various constituencies and thereby facilitate steps towards a more sustainable society (e.g. Dey, Russell \& Thomson, 2011; Gallhofer et al., 2006; Sikka, 2006; Spence, 2009; Gray, Brennan \& M alpas, 2014). By taking a broader view of human impacts and interconnections, such alternative forms of account-giving could challenge the usual norms of accounting, which place the organization in the focus of the account (see Hines, 1988; Milne \& Gray, 2013), and could thereby enhance the visibility of humanity's socio-ecological interdependencies (Bebbington and Larrinaga, 2014). According to Brown (2009), for instance, counter accounts constitute a very important element of democratic contestations, as they can help resist business capture as well as illustrate alternative courses of action and diverse viewpoints². Likewise, Gray et al. (2014) seem to believe that such "new accounts" hold potential to facilitate interstitial transformation, that is, emancipatory projects emerging in the niches of capitalism.

In addition to SEA scholars, also critical accounting researchers have considered the emancipatory potential of counter accounts. Prompted by similar concerns of societal power inequalities and the dominance of particular worldviews, a recent stream of critical accounting literature has discussed how accounting could foster pluralistic democracy, which "recognizes and addresses differentials in power, beliefs and desires of constituencies" (Brown, Dillard and Hopper, 2015, p. 627; see also Brown and Dillard, 2013a, 2013b, 2015; Dillard and Brown, 2012, 2015; Gallhofer, Haslam \& Yonekura, 2015; Vinnari and Dillard, 2016). Brown and Dillard (2013a) maintain that the often-used consensus-oriented models of democracy entail a risk that those in a privileged socio-economic position end up dominating and imposing their own viewpoints in both broader societal discussions and corporate stakeholder engagement processes. The authors perceive various forms of shadow and counter accounts as potentially effective media for giving marginalized constituencies visibility and voice, thereby enhancing the pluralist quality of such debates and discussions. Likewise, Lehman and colleagues (2016, p. 44) point out that counter accounts could offer "a way of challenging prevailing official positions" by providing new knowledge and alternative visibilities to the dominant neoliberal representation.

Despite the emerging interest and recent contributions in both SEA and critical accounting scholarship (e.g. Apostol, 2015; Dey et al., 2011; Gallhofer et al., 2015; Gray et al., 2014; Lehman et al., 2016; Thomson et al., 2015), our knowledge of the use and subsequent effects of counter accounts - and counter-hegemonic projects more broadly, remains inadequate (Brown and Dillard, 2013a; Rodrigue, Cho and Laine, 2015; Spence, 2009). Those with an emancipatory zeal especially perceive a need for more research on the conditions under which counter accounts could engender the sought after transformation (Brown et al.,

\footnotetext{
${ }^{1}$ In this paper we use the term counter account to highlight the contesting nature such accounts often have. Other terms, such as external accounts, alternative accounts and shadow accounts, have also been used, at times with different emphases and connotations (see Dey et al., 2011; Thomson et al., 2015).

${ }^{2}$ Brown (2009) does however point out that on their own, such new accountings are not enough to increase democracy, as they do not ensure a dialogue between stakeholders.
} 
2015). However, as (counter) accounting is a contextualized and contingent practice (Gallhofer et al., 2015), such a call does not imply a search for any 'universal' conditions of possibility. Instead, it prompts us to study the effectiveness of different groups and their strategies in different contexts and stages of a hegemonic struggle (Archel et al., 2011; Thomson et al., 2015; Tregidga et al., in press).

Accordingly, the purpose of this paper is to address this gap in prior research by examining counter accounts' conditions of possibility in a particular context, animal rights activism. M indful of arguments presented in prior research (Gallhofer et al., 2015), we are especially interested in how societal perceptions of the activists and their strategies are associated with the transformative potential of counter accounts. We discuss this issue through a longitudinal case study from Finland, where animal rights activists have actively campaigned against industrial meat and dairy production. A key role in this campaign has been played by videos from pig farms, filmed in secret by animal activists who have taken advantage of unlocked doors at these low security facilities. The videos have been released regularly since 2007 and to date activists have produced such material from hundreds of farms. The film clips, which we conceptualize as visual counter accounts, are available on a website hosted by an animal rights NGO, and some of them have also been shown on national television. The films have received wide publicity, appearing for instance in front-page headlines throughout the national press, in addition to which they have been discussed in the parliament and on other political levels. It nevertheless remains unclear what kind of effects these counter accounts had on the societal perception of the activists and the institutionalized practice of meat production and consumption.

In this study, our main empirical dataset consists of 21 interviews, which we have conducted with activists, politicians, researchers as well as representatives from the meat industry, retail stores, interest organizations and lobby groups. Moreover, for our analysis we have also made use of the websites in which the animal activists have published counter accounts of animal production. Our analysis is further supplemented by other data, including corporate annual and CSR reports, advertisements, media stories, brochures and promotional material, as well as other published material, the inclusion of which has helped us in contextualizing the events.

We base our analysis on two theoretical frameworks. Firstly, the dynamic conflict arena framework presented by Thomson et al. (2015) offers us the conceptual apparatus and necessary vocabulary through which we are able to discuss and describe the development of the events in our empirical setting. Secondly, we draw on discourse theory presented by Laclau and M ouffe (1985) and further developed by Laclau (e.g. 1996; 2001, 2005; see also Glynos and Howarth, 2007; Howarth and Stavrakakis, 2000; Jørgensen and Phillips, 2002) as well as related work in the critical accounting literature (e.g. Brown and Dillard, 2013a, 2013b, 2015; Brown et al., 2015; Dillard and Brown, 2012, 2015; Gallhofer et al., 2015; Tregidga et al., 2014; Vinnari and Dillard, 2016) to discuss especially the identity-related and political effects generated by the production and dissemination of the counter accounts. We highlight how the transformative potential of counter accounts is associated with the way in which the identity of the counter-accountants producing them becomes constructed and understood within a particular setting. In doing so, we seek to contribute to the recent discussions on the societal relevance of counter accounts (e.g. Thomson et al., 2015; Gray et al., 2014, Apostol, 2015) and on the role and possibilities of accounting and accountability in pluralistic societies as proposed by Brown et al. (2015).

As a dominant and taken-for-granted regime within contemporary societies, the meat industry provides a critical case for social and environmental accounting as it is evident that the significant global environmental impacts of meat (and dairy) consumption point to the need for considerable changes to the industry's 
institutionalized position (Vitousek et al., 1997; Rockström et al., 2009; Steffen et al., 2015). M oreover, the scale and necessity of animal production and consumption is also debated due to the associated ethical issues (Pluhar, 2010; Vinnari \& Vinnari, 2014) and public health considerations (M cM ichael et al., 2007; Orlich et al., 2013). Within this context of socio-ecological interdependence and expected transformation, our case study highlights how various social actors react to and privilege particular types of accounts and forms of knowledge in a controversy over the (ab)use of animals. By recognizing the relevance of the global sustainability context in our investigation, we hope to advance the connections between accounting research and significant global problems (Bebbington \& Larrinaga, 2014; Unerman and Chapman, 2014).

Based on our analysis, it appears that when trying to undermine the counter-accountants' radical political demand, the dominant social groups in Finland not only dismissed the counter accounts but also attempted to constitute the counter-accountants' identity as irresponsible, militant and negligent, drawing a firm political boundary and antagonistic frontier between 'them' and 'us'. Likewise, the counter-accountants seemed reluctant to communicate with representatives of the dominant bloc, resulting in an antagonistic as opposed to an agonistic relationship between the two political groups. We claim that, as a consequence of this polarization, the counter accounts succeeded only partially. They managed, to some extent, to rearticulate the meaning of animal production, potentially resulting in the emergence of small-scale societal effects. However, whether or not this will lead to more large-scale change remains an open empirical question. We also discuss ethical questions concerning the production of counter accounts, the importance of having a clearly articulated political vision, and the challenges related to evaluating whether the counter accounts have been successful.

The paper flows as follows. The second section briefly reviews prior research on counter accounts before proceeding to present the theoretical background we draw on in our work. The third section introduces our case study setting in more detail as well as describes the data and methods used in this paper. In the fourth section we present and analyse our findings in light of the two theoretical frameworks. The paper ends with a concluding discussion and implications for further research.

\section{Investigating the effects of counter accounts}

\subsection{Prior literature}

Information is a key element in the functioning of societies as the assessment and evaluation of alternatives form the starting point for most decision-making processes. Information is required and used by various parties, including public authorities, public and private sector organizations, non-governmental organizations and individual citizens. In societies, there are particular dominant narratives, or discourses, which are often founded on the articulations of more powerful social groups, be that the government, private corporations, different interest groups or some other organizations (see Wodak \& M eyer, 2015). However, the information provided in dominant narratives, such as corporate sustainability disclosures, often provide only a partial representation of the world, resulting in reality being constructed from a particular narrow perspective while omitting other world views (e.g. Milne et al., 2009). It has been argued that by providing alternative representations and supplementary information, counter accounts are able to problematise and "make 'thinkable' and 'governable' such issues that are currently regarded as 'unthinkable' and 'ungovernable' by those in power" (Dey et al., 2011, p. 66). Moreover, such 'counter accountings' could reflect, facilitate and 
encourage the voices of diverse interests, as they can be produced with relative autonomy from society's established institutions and power structures (Gallhofer et al., 2015; see also Brown et al., 2015).

Counter accounts appear in various forms, depending for instance on the group compiling the account, the issue in question and on whether the account focuses on a single organization or a broader topic. Dey and colleagues (2011, p. 64) describe counter accounts as "accounting for the other, by the other", implying that counter accounts are usually created by some group outside the organization or the activity in question. The key benefit of counter accounts relates to the possibility to problematize or challenge an organization or an activity, which the group preparing the account considers to have negative or otherwise undesirable social or environmental consequences. One would typically expect a counter account to provide information which either is novel or counters some information produced by the organization or institution under scrutiny (Dey et al., 2011; Harte and Owen, 1987; Thomson et al., 2015). A well-known target of counter accounts are private business corporations, influential actors that readily offer their own narrative of their activities in society through for instance voluntary social responsibility disclosures (Bebbington, Unerman \& O'Dwyer, 2014). Although corporations in their reporting keep highlighting their benevolence and engagement with social responsibility and sustainability, prior SEA research has recurrently noted how these voluntary disclosures tend to provide a one-sided description (see Rodrigue, 2014), in which any negative aspects are either mitigated or omitted in full (e.g. Boiral, 2013; M ilne \& Gray, 2013).

The potential of counter accounts has also been noted by critical accounting scholars, especially in discussions concerning political and other processes that involve engagement with multiple constituencies (see Brown et al., 2015; Gallhofer et al., 2015; Lehman et al., 2016). Stakeholder engagement has often been highlighted as a mechanism that helps various stakeholder groups bring their views to the attention of the management and other decision makers and thereby influence corporate or institutional behaviour (see Archel et al., 2011; Bebbington et al., 2014). It is however evident that within such stakeholder engagement processes all parties do not possess equal power, due to which their views and requests may not be heard or taken into account (e.g. Brown and Dillard, 2013a). In addition, as discussed by Archel and colleagues (2011), such consultation processes may also end up in stakeholders being co-opted (see also Luque-Vilchez \& Larrinaga, 2016). Accordingly, it has been suggested that counter accounts could provide alternative perspectives on both organizational activities (e.g. Apostol, 2015; Spence, 2009) as well as other taken-forgranted social narratives (Cooper et al., 2005; Lehman et al., 2016; Thomson et al., 2015).

However, despite prior research on the use of counter accounts in different situations, we still know relatively little of their effectiveness in influencing longer term change and aspired transformations. One example of counter accounts being employed to influence more powerful social actors is discussed by 0'Sullivan and 0 'Dwyer (2009), who provide insights on the nature of counter accounting related to the launch of a financial sector social and environmental responsibility initiative, the Equator Principles. By using a diverse longitudinal dataset, O'Sullivan and O'Dwyer (2009) focus on "[external accounts'] ability to instigate change through challenging the legitimacy of aspects of organisational activity" (ibid, p. 577). The authors point out how during the process non-governmental organizations (NGOs) sought to influence the financial institutions with different methods of involvement, including external accounts ranging from less confrontational and more systematic (see Dey, 2007) to more antagonistic, confrontational and partisan ones. O'Sullivan and O'Dwyer (2009) conclude that NGOs were influential in the initiation of the Equator Principles and that counter accounting had a role in this accomplishment. 
The use of counter accounts by NGOs has also been investigated by Brennan and M erkl-Davies (2014), who provide a rhetorical analysis of the press releases issued by Greenpeace and several international sportswear firms in a public controversy over the use of hazardous chemicals in the supply chain. Although the authors do not link their study to prior work on counter accounts, their case can be seen as an example of an outside party compiling and releasing information, that is, a counter account, on an accountable entity of interest. In their paper Brennan and M erkl-Davies (2014) highlight how Greenpeace's campaign seemed to be at least a short-term success as the targeted firms had to give in to the demands set by Greenpeace, albeit the authors do note that the longer-term effects remain unclear.

Counter accounts do not however need to emanate from NGOs. Apostol (2015), for instance, presents a case study on a contested plan to open a gold mine in western Romania. The project was faced with unprecedented opposition by a coalition of distinct civil society groups. Apostol (2015) argues that counter accounts were successful in challenging the mining project as they questioned whether the corporate reports presented the mine in a balanced manner; problematized the mining company's approach on social, cultural and environmental impacts of the project; and exposed the state's intentions to favour economic interests over other values. Nonetheless, Apostol (2015) notes that the counter accounts did not seem to change the mining corporation's approach to giving information on the project nor was it clear whether they managed to influence its ultimate outcome.

In developing the paper at hand we draw on Thomson and colleagues (2015), who present a longitudinal case study of the external accounts and other activist practices used by Action on Smoking and Health UK (ASH) in a struggle over tobacco governance during 1999-2010. ${ }^{3}$ Their paper identifies a variety of external accounting practices that ASH used for several purposes and at different stages of the conflict. As a conclusion, Thomson and colleagues $(2015$, p. 805) argue that their study highlights "how external accounts can contribute to the problematisation of governance and development of social and environmental change agendas". The authors further point out that the theoretical and empirical insights provided in their paper could provide a fruitful basis for future research on the use and efficacy of external accounts. In their view, such research would benefit from the use of other datasets than publicly available material, which has been the basis of much recent work on external accounts (see Apostol, 2015; Brennan \& Merkl-Davies, 2014; Thomson et al., 2015).

The ASH campaign against tobacco production and consumption (Thomson et al., 2015) also provides an illustration of how counter accounts are not necessarily produced and focussed on the actions of a single corporation or other organization. Instead, the ASH campaign can be seen to counter broader institutionalized norms and taken-for-granted practices within society. Similarly, in recent years there have been several publicly discussed counter accounts on corporate tax avoidance and evasion (e.g. ActionAid, 2010; see Ylönen and Laine, 2015). Here, the counter-narratives of individual corporations have been used as illustrative case examples in seeking to question a widely spread and institutionalized practice of corporate tax minimization, thereby attempting to pose challenges to wider macro-level power relations (see Archel et al., 2011; Brown et al., 2015).

Similarly to the ASH campaign, the counter accounts examined in this paper are not directed at any individual organization, but rather they seek to challenge a deeply embedded and taken-for-granted social practice, meat production and consumption. Before presenting our analysis in more detail, we will introduce the two

${ }^{3}$ In discussing Thomson et al. (2015) we use the term external accounts, as this is the concept they use in their paper. 
conceptual frameworks employed in this study, the dynamic conflict arena framew ork (Thomson et al., 2015) as well as discourse theory (Laclau and Mouffe, 1985; Laclau, 2005, 2001, 1996).

\subsection{Animal production as a dynamic conflict arena}

In the conceptualization of our empirical setting, we employ the dynamic conflict arena framework presented by Thomson et al. (2015). In developing their framework, Thomson et al. first introduce a typology of external accounting practices, which they thereafter integrate with prior work on conflict dynamics (Beck \& Willms, 2004) and activist intentions and practices (Kneip, 2013). Thomson et al. (2015, p. 838) argue that their dynamic conflict arena framework could be useful by offering "new insights into the complex interactions surrounding the giving and receiving of external accounts in the context of assemblages of social activist practices and inter-connected conflict arenas".

Based on prior work in the social accounting literature, Thomson et al. (2015) present a typology of external accounts, which consists of four broad types of external accounts: systematic, partisan, contra-governing, and dialogic. The types are distinguished on the basis of "differences in the underlying intentions, values and rationalities of those producing the accounts" (ibid., p. 813). Systematic external accounts question some aspects of a target organization's activities, an example being submitting evidence of environmental harm to appropriate regulatory authorities. Partisan external accounts aim at transforming particular technologies, organizational conduct or elements of the dominant governance regime that the actor producing the external account considers unacceptable. Partisan external accounts may have similarities with systematic accounts, but in addition they also blend factual evidence with emotional narratives questioning the moral and ethical nature of institutional conduct. Partisan external accounts can be seen as confrontational as they are used to "antagonize and de-legitimate elements within the existing governance regime" (ibid. p. 814). Contragoverning external accounts are primarily aimed at radically transforming the existing governance regime. Instead of focusing on a particular technology, activity or practice, these accounts strive to "critique the fundamental knowledge base (ideology) of those in power" (ibid., p. 814) and to replace it with their own ideology. Finally, dialogic external accounts recognize and seek to include the diversity of interests in a conflict arena. The producers of such accounts emphasize the need for multiple accounts and utilise the external accounts to identify possible areas of cooperation among the various actors.

Drawing on prior work on the dynamics of conflict situations (Beck \& Willms, 2004; Georgakopoulos \& Thomson, 2008; Power, 2004), Thomson et al. (2015) maintain that a conflict can be seen to consist of five possible main states: initiation, denial, perpetuation, escalation, and resolution. All conflicts do not need to proceed through all five stages, nor do the stages necessarily follow each other in a linear fashion. The conflict initiation state entails that an actor intentionally seeks to disrupt the setting in an arena. This would usually involve a confrontation with some other actors in regard to the legitimacy or acceptability of their activities. Prior research has highlighted that activist groups have used external accounts to initiate conflicts (Cooper et al., 2005; Harte \& Owen, 1987). The conflict denial state implies that some other actor decides to refute the claims made by the actor seeking to initiate the conflict. Denial can emerge in a variety of ways and by different coalitions but it is likely to involve the dismissal of the confronting actor or the veracity of the claims made. Thereafter, the conflict initiator or some other actor may engage in conflict perpetuation by denying the denial. New claims can be made, different media of communication used or alternative emphases sought, depending on the logic used by those denying the conflict. In a conflict arena these stages can follow each other until a resolution is reached or an actor chooses to escalate the conflict. Conflict resolution entails that 
the conflict participants collectively reach an agreement over the contested issue. This could mean that the party challenged in conflict initiation accepts responsibility of the questioned activity. It may well be that a resolution can only be reached if all arena actors accept the legitimacy of the broader governance regime. In contrast, conflict escalation involves not only questioning the other actors' claims but sometimes also challenging the governing regime or powerful institutions.

Thomson and colleagues (2015) emphasise that the proposed framework is not offered as a definite framework or a normative model but rather as a heuristic which could provide insights on the complex processes related to giving and receiving accounts and knowledge claims in conflict settings. In this vein, we perceive that their heuristic allows us to conceptualize the focal conflict arena of this paper. The counter accounts produced by the animal rights activists since 2007 can be classified as partisan as they provide an alternative, emotionally staged narrative seeking to confront and subsequently transform a dominant regime - meat production and consumption. In the fourth section we will discuss in more detail how the conflict proceeded through various stages, and how the diverse social actors perceived the role and use of the counter accounts in the conflict. Before proceeding to the analysis, however, we introduce the conceptual tools offered by discourse theory (Laclau and Mouffe, 1985; Laclau, 1996, 2005), which allows us to explore both the presentation of knowledge claims as well as the construction of various group identities during the conflict setting, thereby shedding light on how an antagonistic frontier emerged over time.

\subsection{Discourse theory}

Discourse theory (Laclau and M ouffe, 1985; Laclau, 2005, 1996) is one of the many varieties of discourse studies (see Angermuller et al., 2014; Wodak and M eyer, 2015). Introduced first jointly by Laclau and M ouffe (1985), and subsequently developed by Laclau (e.g. 2005, 2001, 1996), discourse theory has its basis in two significant theoretical traditions: Marxism and structuralism. In Laclau and Mouffe's poststructuralist approach, Marxism provides the foundation for conceptualizing the social, whereas the relational understanding of meaning derives from structuralism (see Howarth and Stavrakakis, 2000; Jørgensen and Phillips, 2002). More specifically, Spence (2007) points out how Laclau and Mouffe (1985) base their work within the Gramscian tradition, in which social relations are considered to be reproduced in the cultural realm instead of being predetermined or pre-given through a class-base as in structural Marxism. ${ }^{4}$ After their seminal book Hegemony and Socialist Strategy (Laclau and M ouffe, 1985), Laclau and M ouffe have in their later work each emphasized different aspects of the political sphere and developed to an extent distinct theoretical considerations of the social and the political (e.g. Laclau, 2005, 1996; Mouffe, 2013). Given its focus on power and conflict, we maintain that discourse theory as advanced by Laclau (see Laclau, 1996, 2001,2005 ) is well suited to the purposes of this study, as it also offers conceptual tools for an investigation of the construction of meaning and identity within social struggles.

One of the key ideas in discourse theory lies in the contingency of all social phenomena, implying that no meaning is ever ultimately fixed. In line with structuralist linguistics, Laclau and M ouffe (1985) maintain that instead of receiving meaning through a relationship with some outlying reality, different signs do so through their relationship to other signs, that is, by being different from one another. M oreover, and in contrast with structuralist theory, the meanings and positions of signs are not locked, but each sign can have various

\footnotetext{
${ }^{4}$ It is worth highlighting that Laclau's position in relation to key left thinkers such as Marx and Gramsci has been contested (see Anderson, 2016; also Butler, Laclau and Zizek, 2000).
} 
meanings depending on the context in which they are used ( $\emptyset$ rgensen and Phillips, 2002). As all meanings are contingent, social settings are imbued with constant struggles concerning the definitions of signs (Laclau and M ouffe, 1985; see also Howarth and Stavrakakis, 2000; Spence, 2007). Different actors seek to embed signs with their own particular definition, at times resulting in such meanings becoming temporarily fixated. In line with other discourse analytical traditions (see Wodak and M eyer, 2015), Laclau and M ouffe (1985) argue that struggles over meaning have concrete and tangible social effects. Within this context, Jørgensen and Phillips (2002, p. 25-26) postulate the aim of discourse analysis to be "to map out the processes in which we struggle about the way in which meaning of signs is to be fixed, and the processes by which some fixations of meaning become so conventionalized that we think of them as natural".

Amongst the core concepts introduced by Laclau and M ouffe (1985) to discuss the construction of meaning were articulation, element, moment and closure. Articulation is understood as "any practice establishing relations among elements such that their identity is modified as a result of the articulatory practice" (Laclau and M ouffe, 1985, p. 105). The articulations, which can comprise both linguistic and non-linguistic practices, position signs in relation to other signs, thereby giving them a particular meaning. In Laclau and Mouffe's terms, an element implies a sign for which there are various different and competing understandings. An element can be reduced into a moment, if it is defined in a specific and unambiguous way. Discourse then can be defined as "a fixation of meaning within a particular domain", or in more specific terms, an attempt "to transform elements into moments by reducing their polysemy to a fully fixed meaning" ( $\emptyset$ ørgensen and Phillips, 2002, p. 27-28). As noted above, a total fixation of meaning can never be achieved, but discourses can nonetheless reach closure, entailing a temporary fixation of the meanings of signs in a particular domain (Laclau and M ouffe, 1985). Discourses can also become sedimented, which entails that they have through historical processes become so firmly established that no alternatives are usually ever seen. Given the contingency of all social, however, actors can at any time contest such a sedimented discourse by new articulations and hence open it up to political contestation and struggle (see Jørgensen and Phillips, 2002, p. 36).

In no domain are all signs of equal significance. Laclau and M ouffe (1985) refer to nodal points, or "privileged signifiers within a discourse that bind together a particular system of meaning" (Tregidga et al., 2014, p. 479). Nodal points are of importance, since other related signs acquire meaning through their associations with the nodal point. By themselves, nodal points are empty of meaning and hence they play a key role in social struggles as the temporarily fixed meaning of a nodal point affects the meaning of other signs related to it (Laclau and M ouffe, 1985, p. 107). A well-known example of a nodal point in the global arena is sustainable development (Tregidga et al., 2014), which different parties and interest groups seek to fill with a meaning that serves their respective interests. In our empirical setting, the key nodal point over which a struggle takes place is that of animal production. We argue that prior to the initiation of the animal rights activists' video campaign there was a temporary closure of meaning in the discursive domain of animal production in Finland, affecting both the things that were considered important and how various groups were understood in society. In fact, meat production and consumption as well as the associated human-animal relationship were so normalized that we can perceive the discourse to have become sedimented, with no alternatives usually presented (Laclau and M ouffe, 1985). With the broad publicity the counter accounts received, the activist campaign contested this sedimented discourse and sought to redefine and rearticulate the nodal point of animal production, leading to a socio-political discursive struggle and to various consequences on different levels. 
In addition to the construction of meaning, an important feature of discourse theory (Laclau, 2005, 1996; Laclau and Mouffe, 1985) is its understanding of identity, which is seen to be defined, constructed and organized according to the same principles in similar articulatory and discursive processes as the meanings of signs. Likewise, group identities and formations are not predetermined but constructed and constituted through discourses. Groups are thus contingent and become formed in the process of their representation. The identities of particular groups are relevant, as these also affect the way the groups are perceived within social settings, which is significant in struggles where the groups seek to fill particular nodal points with meaning (Jørgensen and Phillips, 2002). Taking the concept of sustainable development as an example again, it makes a difference whether the business community becomes represented as 'greedy capitalists' or 'green entrepreneurs'. As Tregidga and colleagues (2014, p. 480) put it, "a consideration of the formation of group identity construction through discourse therefore requires a focus on articulations that constitute particular groups through representation, and would further consider the understandings that are implied."

As is the case with elements, identities are always defined in relation to others, that is, a group is something because it is contrasted with something else. Here, Laclau and M ouffe (1985) put forward the ontological idea of radical negativity, which refers to how some objects, be they signs or identities, gain their meaning only through a reference to what they are not. Marchant (2004, p. 59) describes radical negativity to entail something "inherently different, incommensurable, threatening and exclusionary". In other words, the discursive construction of especially collective identities implies drawing a political boundary between 'us' and 'them' through opposition and negation (see Vinnari \& Dillard, 2016). In developing his political theory further in his later work, Laclau (2005) elaborates on such political boundaries through the concept of antagonistic frontier, which he uses to highlight how society can be thought of as "two irreducible camps", between which we cannot move as they are separated by a fundamental chasm (see Laclau, 2005, p. 84-86; see also Spence and Shenkin, 2008). In this context, Laclau (1996) also makes the distinction between universalism and particularism by highlighting how in societies various groups struggle to achieve a dominant position, in which their own particularism would (temporarily) achieve a universal representation. Through such "universalization of its own particularism" (Laclau, 1996, 24), the identity of the dominant group becomes constructed as representative of universal values and viewpoints, thereby making this particular group distinct from the various other particulars in society, as well as also fading away its own particular nature. Together, these concepts developed by Laclau $(2005,1996)$ are of considerable use in discussing the conflict setting presented in this paper, as they help us to conceptualize and subsequently understand how and why the identities of particular social groups are constructed as enemies in the political struggle. Moreover, for the purposes of the present paper a similarly relevant concept is that of chain of equivalence, which was introduced by Laclau and M ouffe (1985) and entails how "signs are sorted and linked together in chains in opposition to other chains which thus define how the subject is, and how it is not" (Jørgensen and Phillips, 2002, p. 43). Disparate social groups, each with their own interests and disadvantages, can join forces and create an alliance in seeking to transform an existing social power formation. In her later works, M ouffe (2013) has emphasized that the formation of chains of equivalence is imperative for diverse social movements trying to construct a counter-hegemonic discourse leading to social change.

In what follows we use these conceptual tools to shed further light on the role of counter accounts and the counter-accountants in the envisaged transformation of institutionalized socio-economic practices. The framing of meat production and consumption in Western countries has arguably resulted in a dominant discourse, with large-scale industrial animal production and mass consumption being the norm. Meat production and consumption have however been shown to be related to detrimental environmental impacts, considerable public-health issues, as well as ethical dilemmas related to the justification of meat eating (see 
Orlich et al., 2013; Pluhar, 2010; M cM ichael et al., 2007; Vinnari and Vinnari, 2014). In the case we investigate in this paper, we perceive animal production to be the nodal point, over the meaning of which a social struggle has taken place. In the same discursive process, the identities of the key adversarial groups have also become represented and reconstituted. Such groups include, for instance, farmers, regulatory authorities, veterinarians, as well as the activists themselves.

We will next discuss how the counter accounts in the form of video materials affected the constitution of discourses and signs as well as the reconstruction of the relevant identities, and subsequently consider what kind of implications such representations and understandings have had in society. First, however, an elaboration of our research material and method is in order.

\section{Data and setting}

Our empirical investigation in this qualitative case study takes place in Finland, where in 2007 animal rights activists $^{5}$ launched an active and broadly noticed campaign against industrial meat production and consumption. As many animal farms in Finland have been relatively easily accessible, the activists have secretly entered the farms at night to film the premises and the conditions in which animals are kept. The idea of the campaign is coined in one of its slogans: "Cruel truth: a research study of Finnish animal production". The videos have been released regularly since 2007, and to date the activists have produced material from over a hundred piggeries. ${ }^{6}$ The clips have been made readily available through websites ${ }^{7}$ hosted by an animal rights NGO, in addition to which they have also been shown on national television. Upon their release in 2007 the films received broad press coverage and attention in public discussions (see Figure 1). This may be partly related to the fact that animal rights activists in Finland had in previous years mainly operated in rather conventional ways, such as by distributing leaflets and organizing small scale events. The videos, which we conceptualize as visual counter accounts, were hence a new tool through which the activists sought to further their cause.

INSERT FIGURE 1 ABOUT HERE

\footnotetext{
${ }^{5}$ Animal rights activism can be seen to have developed from the more traditional movement focusing on animal welfare, the key difference between the two being that whereas animal rights activists seek to get rid of all use of non-human animals for food, clothing and other purposes, the welfarists are content with aiming at enhancing the conditions where individual animals are kept (see Francione, 2010; Regan, 1983; Singer, 1975). According to Konttinen and Peltokoski (2004), in Finland activists disappointed inter alia with the bureaucracy and perceived inefficiency of traditional animal welfare organizations in achieving aspired socio-political changes began to coalesce around the issue of animal rights in the early 1990s, and in 1995 they formed a non-hierarchical organization called Oikeutta Eläimille at least partially inspired by the US-based organization PETA, or People for the Ethical Treatment of Animals.

${ }^{6}$ At the time of its launch, the campaign included material from both piggeries and chicken farms. It soon turned out however that the media outlets (and the public?) were more interested in describing and discussing the pig videos than those filmed at chicken farms. The first batch of videos was released at the beginning of the holiday season in 2007, and we hence speculate that the interest towards pig farms was largely due to role ham has as The Traditional Finnish Christmas Dish, which is akin to that of turkey in the USThanksgiving festivities. In this paper our focus is on the piggeries and pig videos, as they gained most of the attention in the first stage, and were the main focus of the campaign in the years that followed.

${ }^{7} \underline{\text { www.tehotuotanto.net; }}$ www.sikatehtaat.fi; www.elaintehtaat.fi
} 
Our primary dataset consists of 21 interviews, which we have conducted with actors from various sectors of society, including animal activists, other NGO actors, academics as well as representatives from government, the meat industry, the retail sector and lobby groups (see Appendix 1). The interviewees were selected based on different rationales. We interviewed the two animal activists who had publicly proclaimed having taken part in the filming of the piggeries. The other NGO actors include prominent figures in major Finnish environmental or animal rights organizations. The interviewed politicians and ministry representatives have been in influential positions during the process or alternatively have taken an active role in the discussion regarding animal production. The interviewees from the major Finnish corporations in both the meat industry and the retail sector were selected on the basis that they were in charge of animal welfare or corporate social responsibility within their organizations. The farmers' interest group is a major political player in Finland, and the interviewed representatives discussed pig farming from the economic, social and environmental perspectives, hence providing us with a broader view of agricultural production in Finland. Finally, the interviewed academics approach agriculture and animal production from different perspectives in their work and were hence able to provide some broader views on the research topic.

Although it could be argued that the 21 interviews we have collected only forms a small sample, we maintain that as our interviewees represent a broad range of social groups around animal production, their complementary perspectives provide a comprehensive view on the conflict. Moreover, it is worth highlighting that our set of interviewees features numerous prominent figures whose views have received substantial press coverage over the past years and therefore may have played a considerable role in the construction of meanings and identities related to animal production.

Several supplementary datasets were also collected for this study. These include the secretly filmed video clips from the pig farms over the period 2007-2013, available on websites hosted by an animal rights NGO. Some of these clips have also been shown on national television. In this paper we do not conduct a detailed analysis of these video clips $^{8}$, since our interest here is more in how the videos and their contents have been perceived by the various social groups and which kinds of societal actions, if any, the videos have prompted. We have, however, made use of the websites hosting the videos in our analysis, as the combination of videos and the accompanying textual material discussing the videos and the campaign have helped us in forming a more nuanced understanding of the activists' (pronounced) aims and logic. We have also collected annual and CSR reports published by the companies in the meat industry; newspaper and magazine articles; court records; as well as promotional material and brochures published by various actors. The archival media data has provided us insights on how the counter accounts were represented in the public domain and on the views presented at the time the videos were released. The material published by companies and other organizations show us how the annual and CSR reports as well as the promotional materials have changed during the course of the campaign. We do not proclaim that our analysis of these supplementary materials should be considered as definite and exact; we do nonetheless maintain that all this material has been valuable for us as it has helped us build a more coherent understanding of the events and thereby to place the interviewees' views within a broader context. M oreover, it is also worth pointing out that we conducted the first indicative round of analysis of our supplementary material before commencing with the interviews; an analysis of the other material was essential, as it both guided our interviews towards the questions we

\footnotetext{
${ }^{8}$ Elsewhere, we utilize the work of Chouliaraki (2006) and Boltanski (1999) to provide a discursive analysis of the secretly filmed video material and an episode of a major Finnish television show discussing the videos (Vinnari \& Laine, 2017).
} 
considered relevant, and also provided us with detailed knowledge of the campaign, which enhanced our ability to discuss the events with our interviewees.

The interviews, which lasted on average for about an hour, took place between December 2013 and June 2014. Both authors were present at 16 out of the 21 interviews, while the remaining five interviews were conducted solely by one of us. A generic interview guide (see Appendix 2) was developed in advance, although the content and emphasis of the interviews was adjusted for each interviewee as their backgrounds and roles in the case were substantially different. Each interview was recorded and subsequently transcribed verbatim. In the analysis, we proceeded over numerous rounds of reading, interpreting, re-reading and reinterpreting. Both authors studied the interview transcripts independently and formed their own personal understanding before a joint interpretation was reached via an iterative process of discussion and reinterpretation. Over the course of the analysis we have been guided by different theoretical framings, which have steered our focus on particular aspects. Already at an early stage of the analysis we utilized the framework presented by Thomson et al (2015) in developing our interpretation over how the activists' campaign and the social conflict proceeded over time. For the present paper, we adopted the discourse theory first presented by Laclau and M ouffe (1985) and subsequently developed by Laclau (2005, 1996), and recoded and reanalysed the dataset with the aid of the key concepts of their work. ${ }^{9}$ At this stage of the analysis we conceptualized the conflict setting as a discursive struggle and focused our analytical efforts on how the various parties sought to fulfil the nodal point, animal production, with meanings suiting their own particular interests, as well as attempted to transform certain signs from fairly sedimented moments into elements by contesting the normalized meaning of those signs. Moreover, we also concentrated on investigating how the identities of different groups were articulated in relation to both signs as well as to other groups.

Upon reflection, it is also evident that our own worldviews have affected our reading and interpretation of the events, commencing already in our decision to examine this very topic and to make use of discourse theory (Laclau and M ouffe, 1985; Laclau, 2005, 1996). As scholars, we are convinced that the broad range of sustainability-related questions (Steffen et al., 2015) require urgent attention. Moreover, we remain attentive of the vested interests that feature in the political decision-making processes, and maintain that along with all other taken-for-granted truths the hegemonic political logics of societies require constant appraisal and challenging (see Tregidga, Milne and Kearins, in press). As with all social sciences, we readily admit that the interpretations and narratives presented here are inherently subjective and to an extent value-laden. Others may, should they wish to do so, produce their own interpretation of this conflict and of these utterances through different framings and from their personal worldviews (see Milne et al., 2009). M eanwhile, we now proceed to present our interpretation in the section that follows.

\section{Analysis of the conflict stages}

In this section we will present our empirical findings, drawing on the two aforementioned conceptual frameworks to describe how the conflict proceeded over the years through various states. We will also discuss how the various social groups engaged in the discursive struggle sought to rearticulate the meaning

\footnotetext{
${ }^{9}$ We are grateful for the anonymous reviewer for this suggestion.
} 
of animal production and other related signs, as well as engaged in attempts to reconstitute the identities of other groups.

\subsection{Initiation}

The conflict can be seen to have initiated in late November 2007, when some material filmed by the animal rights activists was first aired on the prime time news programme A-Studio, followed by the opening of a dedicated campaign website hosting videos from 60 pig farms from different parts of Finland.

We conceptualize the video material as a partisan external account (Thomson et al., 2015), aimed at questioning the taken-for-granted social practice of industrial meat production and consumption. The counter accounts provided an alternative narrative to both the information produced by the meat industry and the broader dominant discourse of animal production:

"Before these images [the videos] there was nothing visual, no other message except for the animal rights activists' calls from the side lines. (...) And then there was the [meat industry's] advertising imagery which had been constructed for years and which is completely out of space. It was a huge achievement that we managed to shed light on what an animal's everyday life looks like. And just because it is so extremely different from the advertisements, the power of the [filmed] image has increased hugely. I believe that it has changed the way in which we talk about animals. (Activist, cameraperson B)

By disseminating the videos the counter-accountants ${ }^{10}$ sought to confront and subsequently transform the dominant social discourse. In the terms of Laclau and M ouffe (1985), the video material from the pig farms, as well as the campaign more broadly, aimed at rearticulating the meaning of animal production. As mentioned in passing in the quote above, the dominant discourse had prevailed for years, and was constantly reinforced through for instance advertisements portraying a romanticized version of the Finnish countryside as well as the meat industry's CSR reports featuring photos of farmers and endearing animals in symbiotic postures. With the video clips the activists contested the way animal production is defined in society, in other words they sought to rearticulate the nodal point and fulfil it with a meaning that contrasted sharply with the sedimented discourse. Simultaneously, through rearticulating the nodal point of animal production the campaign also opened up the meaning of other signs and group identities, that is, turned moments back into elements and thus open for contestation (see Laclau and M ouffe, 1985; Jørgensen and Phillips, 2002). For instance, the activists questioned the ideas and requirements usually associated with animal welfare. Likewise, in representing video material from a broad range of farms, the counter-accountants disrupted the often-heard articulation of how the Finnish farmers always fulfill the tightest of quality standards.

The interviewed activists who had participated in filming the piggeries had similar views about the partisan nature of their counter accounts, one core aim of which was a change in the existing governance regime. Following Laclau and M ouffe (1985), we can speak of a radical political demand, which publicly questioned the norms of a social practice in the name of an ideal (see Glynos and Howarth, 2007). Here, it is worth noting that for Laclau and M ouffe (1985) such a radical political demand is not only about the State or some other ruling institution, but it is also linked to demands aiming at a "transformation of a social relation which

\footnotetext{
${ }^{10}$ The term "counter-accountant" refers to the individuals who took part in the production of the counter accounts. We use the terms "activist" and "counter-accountant" interchangeably when discussing our empirical case.
} 
constructs a subject in a relationship of subordination" (p.153). Thus, the counter-accountants sought to change both the dominant governance regime and the way in which animals were perceived in society:

"[0]f course I want a world where animals are taken into consideration as individuals with their own interests, and their interests rarely meet ours. Of course I want that the present kind of animal industry is abolished completely." (Activist, cameraperson A)

"It is not a conflict between animals and producers or animals and meat eaters but it is a societal state where we have a certain way of seeing animals. (...) [T]o put it concretely, first of all I would like people to eat and consume fewer animals as products, and second, I would like that our conception of animals would change." (Activist, cameraperson B)

These statements contain clear references to the philosophical views according to which animals are sentient individuals with a right to their own lives (see Francione, 2010; Regan, 1983). There is little question that the activists attempted not only to redefine the nodal point of animal production as being an immoral practice but also to rearticulate the identity of production animals as sovereign beings instead of production machines or raw material. Thus, their aim in producing the films and initiating a conflict in society was to effect a radical reduction and, ultimately, abolishment of animal production. Furthermore, these counter accounts differed from previous ones by having been designed for the broader public:

"I think our message has not been targeted to anybody in particular, but we kind of want to reach everybody. I guess that it sinks in best with a young urban female, who easily becomes a vegetarian and who responds to the images in the way we wish. But of course we hope that our message would be accepted by the whole society." (Activist, cameraperson A)

"It is one of the major things that the animal rights movement has done, targeting a really large audience. So instead of using visual design or rhetoric directed at young urban anarchists, it was the first time we wanted to address everybody. (Activist, cameraperson B)

In the days following their release, the videos and their subject matter featured on several prime time television news broadcasts and on the front pages of major national newspapers and tabloids. This can be said to constitute an intermediate political milestone for the activists as they succeeded in making animals and animal farming a topic of public debate for several days. The counter accountants had managed to provide the public with an alternative representation of the conditions in which animal production takes place, and thereby contested the normalized meanings of several related signs and identities. The discursive struggle over the meaning of the nodal point was opened, implying that other social groups such as government representatives, farmer interest groups as well as the meat industry could also present their own (re)articulation. 


\subsection{Denial and perpetuation ${ }^{11}$}

The institutional response to the counter-accountants' claims was denial. Immediately after the release of the videos, the industry regulators ordered inspections to some of the pig farms in question although their investigation swiftly resulted in a statement pointing out that virtually all problems were just minor and required no immediate action (leading national newspaper Helsingin Sanomat, 11.12.2007). Stronger views were presented by for instance the farmers' interest group:

"A veterinarian [identity withheld] representing the farmers' interest group M TK thinks that the animal right activists' claims are exaggerated. According to her the EU inspections prove that production animals in Finland are well treated in most cases. Moreover, she emphasises that 'we need to remember what kind of an organization we are dealing with. They [the activists] try to stop animal production and are surely purpose-oriented here`." (Newspaper Helsingin Sanomat, 30.11.2007.)

The M inistry of Agriculture and Forestry promised to look into the matter and make improvements where necessary, although the Minister was also highly critical of the methods employed by the activists and of them first withholding the information for several months before making the matter public:

"If one notices animal abuse, one should inform [the authorities], instead of producing secretly filmed videos." (Minister of Agriculture and Forestry quoted in newspaper Helsingin Sanomat 2.12.2007.)

Both of the quotes above show how the dominant bloc, in addition to contesting the veracity of the counter accounts, began to articulate their position through producing a representation of the activists. As Laclau and M ouffe (1985) posit, the identities of social groups are constructed in similar discursive processes as those of other objects and signs. Here, the activists are immediately distinguished from the other groups, who are bound together in a chain of equivalence: the veterinarians, farmers and EU inspectors unanimously agree that production animals are well-treated and the activists "purpose-oriented". The counter-accountants' rearticulation of the nodal point of animal production is thus contested by constructing their identity as an untrustworthy group operating in a clandestine manner. Here we can see the emergence of an antagonistic frontier (Laclau, 2005): 'they', the dubious activists, are separated from the rest of 'us' who obey the rules of the society.

Once the public discussion waned in a few weeks after the release of the first batch of videos, there was not much follow-up on the theme and the matter largely disappeared from the public arena until November 2009 , when the counter-accountants came out with another set of videos from 30 pig farms. With the new counter accounts the activists highlighted that despite some promises made after the initial release of the material, no changes had taken place in the pig farms' living conditions. This second set of films again sought to rearticulate the nodal point of animal production, in addition to which it also questioned the conduct of institutional actors, including some prominent politicians, by challenging their claims of having fulfilled their promises. Yet again the counter accounts featured in major newspapers and were also discussed on

\footnotetext{
${ }^{11}$ The conflict has of course been less straightforward than what is presented here. As noted by Thomson and colleagues (2015), conflicts do not necessarily progress in a linear fashion, nor do they necessarily go through all stages. In our case, the conflict seemed to circle for some time between the denial and perpetuation stages, where the boundaries are also less clear. For clarity, we discuss these phases as if there had only been one stage of denial and another of perpetuation, although acknowledging that these also intertwine.
} 
prominent TV shows. Throughout this process, the dominant governance regime actors denied the counteraccountants' claims and refused to change their own articulation of animals and animal production.

"M inister of Agriculture and Forestry says that 'within two days we will come to know what the reality on the farms is. If there are deficiencies, I won't accept them at all. ' (...) The M inister also highlights that the Finnish legislation is currently in order (...) and that problems have only been found in a fraction of all pig farms." (Interview of M inister of Agriculture and Forestry reported by National Broadcasting Company Yle 11.12.2009.)

It seems that from the beginning the counter-accountants were aware that their material would likely be played down and its authenticity questioned. One reason for this is in all likelihood that in previous years, photos from farms located abroad had been disseminated by Finnish animal rights activists without an explicit mention of their origin. Regardless of whether such an omission was purposeful or not, it sowed seeds of distrust towards material produced by the activists. As put by a journalist after the publication of the first set of films:

"(...) from the perspective of the media, [the animal rights group] Oikeutta Eläimille has not been a very trustworthy organization." (Newspaper Helsingin Sanomat 2.12.2007.)

From the discourse theoretical perspective, this represents another attempt to define the identity of the counter-accountants in negative terms. It is no wonder, then, that the activists tried to pre-empt such attempts by including, on the websites containing the films from Finnish farms, several references to the material being complete and providing a truthful presentation. The counter accounts are coupled with the slogan "cruel truth", and their origin and filming are described as follows:

"Our research was initiated by the need to expose the cruel secret in the middle of which we all live. (...) We stepped inside these buildings, because we wanted to reveal the truth of the everyday life of animal production in Finland." 12

"The conditions for filming were difficult and we only had cheap cameras at our disposal. The exposure of some pictures has therefore been adjusted afterwards. Some pictures have also been focused. The pictures have not been edited otherwise. The video material has not been altered apart from adjusting the lightness. With this we can ensure that the videos and the photographs portray what we have seen on the farms as truthfully as possible." 13

Similar expressions were also used by the representatives of the animal rights NGO when interviewed about the filming:

"The videos provide a comprehensive and representative picture of intensive farming in Finland." (Spokesperson of Oikeutta Eläimille quoted in newspaper Helsingin Sanomat, 30.11.2007.)

Despite the assurances presented on the NGO website and in public settings, the counter accounts have indeed been constantly questioned, and similarly has the justification of the initiated conflict over animal production been denied. Here, the dominant bloc can be seen to assume a universalist position (see Laclau,

\footnotetext{
${ }^{12} \mathrm{http}: / /$ www.oikeuttaelaimille.net/ttnet/.

${ }^{13}$ http://www.oikeuttaelaimille.net/ttnet/index.php?option=com content\&task=view\&id=19\&ltemid=31
} 
1996), placing itself above the particularist claims of the activists, and attesting to possess objective and true knowledge of how animals are taken care of on Finnish farms. The authenticity of the films and the selection of the animals portrayed as suffering have featured prominently in such arguments, as evinced by our research material:

"I would have to go there myself to make sure that it's not a sham" (M inister of Agriculture and Forestry commenting on the films on national TV, 9.12.2009.)

"It's the same thing as if you [the interviewee] were lying in your bed, I can't tell if you've been there for a week or if you've just gone there, have you been neglected or what. So this is how the filmed material can be used for manipulation, and I think they [the activists] did it in a very efficient way. " (Representative from M inistry of Agriculture and Forestry.)

M oreover, the dominant bloc has continuously attempted to downplay the accusations also by delegitimizing the counter-accountants, by trying to represent them as irresponsible and incompetent.

"Well, I primarily think of [the videos] from the perspective of animal diseases, and I find it very sad that this argument is dismissed as irrelevant. (...). So my first thought, and our [company's] as well, is that [the secret filmings] were irresponsible acts, since you could thereby cause significant economic losses and also damage the welfare [of the animals]." (Corporate representative, meat industry.)

"(...)So they [the activists] don't have the competence to interpret these images but they have still interpreted them in public with the consequence that a farm owner lost his mental balance." (Representative 1 from Ministry of Agriculture and Forestry.)

Despite having their claims denied for a variety of reasons, the counter-accountants continued to perpetuate the conflict not only by publishing further videos but also through other means in response to the denial, in other words by denying the denial. As described by an interviewee from an environmental NGO not directly involved in the conflict:

"There were many successful elements. (...) Like when the Chairman of the Pig Farmers' Association said that these [filmed farms] are just isolated cases, the activists published videos from his own farm. Or likewise the material from the family farm of the M inister of Agriculture and Forestry of the time. (...) And when there was discussion about the illegality of the filmings and the anonymity of the camerapersons, then they brought in a new element as two camerapersons came into publicity. (...) So in a way they [the activists] have managed to deflect the questioning arguments one-by-one." (NGO Actor, Environmental NGO.)

As mentioned above, the counter accounts were originally released anonymously, but in the aftermath of the release of the second set of films in 2009 two activists who had taken part in the filming came to publicity. By bringing their names and faces into the public domain, the counter-accountants can be seen to attempt to reconstruct their own identity, which the dominant bloc had publicly associated with negative attributes such as irresponsibility and manipulation. The activists also spoke of their feelings and brought a human face to the video clips, the origins of which had until then remained under a veil of secrecy. We maintain that this was also done in an attempt to enhance the acceptance of their own articulation of animal production and the associated radical political demands within the discursive struggle. Similarly, with reference to Laclau (2005), we maintain that by releasing filmed material from farms associated with the dominant bloc, such as the family farm of the M inister of Agriculture and Forestry, the farm of a board member of a major Finnish 
meat corporation, and the Chairman of the Pig Farmers' Association, the counter-accountants sought to shift the antagonistic frontier, so that these influential figures would become seen as culprits despite their continuous reassurance that they are highly concerned of animals' well-being. The discursive struggle in this case is clearly not only about the meaning of signs, but also about the associated identities (see Jørgensen and Phillips, 2002; Laclau, 1996; Tregidga et al., 2014).

After coming to publicity the activists were subsequently sued by two farmers on the grounds of libel and invasion of private property. The ruling of both the Lower Court in 2011 and the Court of Appeal in 2013 was similar: the material presented in the counter accounts was authentic and their release was lawful. Still, most interviewees continue to hold serious doubts over the videos, evaluating them in more or less explicit scientific terms:

"As a researcher I would have wanted to see images in which they [the activists] would have come in the [piggery] door and then constantly zoomed through all the pens. That would have given an impression and that's how welfare for instance is measured, that you go through them [the pens]. Although in that case you do construct a sample, but that sample is constructed before you even go in the piggery, so you choose for example every third pen." (Academic, animal welfare.)

"Considering that you're researchers, we could [scientifically] evaluate that material [the films]. So they would need to give sample statistics, like, how many doors did you try? How many of them were locked and how many hours of filmed material do you have and how many minutes of that were the most outrageous ones that were publicized? In other words, the background information also [should be given]. If they told us all that, then we could actually evaluate with some degree of reliability whether or not it was a good sample. But now it's not objective. It's subjective." (Corporate representative, meat industry.)

The quotes above illustrate how other actors continue to remain sceptical towards the counter accounts and seek to forge the identity of the counter-accountants as being biased and sloppy in their work, despite the broadly publicized court rulings, which had considered the counter accounts to be authentic. Further, throughout the conflict in our empirical setting, the plea conveyed by the counter accounts has been undermined by dominant groups' questioning of the animal right activists' motives and interests:

"It must be the militant faction [of the activists] who employ these means. Whether they reveal their faces or not, I think it's in a way very one-sided and purpose-oriented because they don't, in my opinion, see the whole at all." (Representative, Farmer interest group.)

"I would approve of it [filming in secret] if it had been about improving animal welfare because then they would have gone in there [in the piggeries] in secret and delivered the material immediately to the authorities and an inspector would have gone there the next day. If the situation had been real, we would have caught them [the farmers] in the act. Then it [the filming] would have improved the animals' wellbeing (...) I think it's evident that they [the activists] are against meat production but if their motive had been to act on behalf of the animals, then I would have been ready to accept it." (Representative 2 from M inistry of Agriculture and Forestry.)

In terms of identity construction, it is also worth noting that only the counter-accountants were represented by several interviewees to be purpose-oriented, whereas other actors such as the meat industry, the farmers' interest group and the politicians were seen as more neutral, rational and capable of comprehensive evaluation of the acceptability of animal production. These other social groups were hence not considered 
to present any particular claims from a specific value-laden viewpoint, but were instead seen to be part of the universal. The struggle over animal production is thus not taking place between several particular groups each representing their own particularist interests and values, but, rather, we are witnessing a setting in which the universal is being questioned by a particular group of counter-accountants not willing or able to share the common values (see Laclau, 1996). An interesting contrast can for instance be noted with regard to whether the credibility of the counter accounts differs from the accounts given by the meat industry, the visual material of which at times offers a very different portrayal and imagery of production animals. Whereas the counter-accountants' selection of the visuals is questioned by most interviewees, the use of corporate promotional material for window-dressing purposes is played down:

"Oh well, that is advertising to my understanding. And now, in my view, informing and advertising, there is a very clear distinction between those." (Representative, Farmer interest group.)

Taken together, we maintain that besides the authenticity of the video material one of the key discursive struggles in the conflict has taken place over the construction of the identity of the counter-accountants. In some sense, the dominant social groups tend to construct the activists through radical negativity, that is, by highlighting attributes that the latter do not possess. The counter-accountants are not like researchers and their accounts do not constitute robust evidence, because they have not been produced according to proper scientific methods. The counter-accountants are not like farmers, who take care of the animals and focus on their welfare. The counter-accountants are not like veterinarians, who understand the animals' needs and natural behaviour, and are thus able to carefully interpret the big picture. Nor are the counter-accountants like the authorities, who are able to conduct a neutral investigation and make balanced judgements aiming at the benefit of the whole society. Thus, the activists are constructed as sloppy, careless and purposeoriented individuals, who are negligent of animal welfare in their pursuit of a personal ideology.

\subsection{Escalation and resolution}

After several years of circling back and forth in the denial and perpetuation stages, it appears that the conflict has eventually subsided. The counter-accountants have continued to add some new videos to their website, although the scale of the filmings is very small compared to the initial stages. M edia attention has also waned down:

"Last Christmas [2013] there were again some attempts at scandalous videos, but nobody was interested anymore. Not even Hesari [newspaper Helsingin Sanomat] bothered to report anything." (Corporate representative, M eat Industry.)

Moreover, a realization has emerged that substantial changes in such taken for granted social processes would require more efforts than just the release of the videos:

"Probably these videos have made many consumers and citizens think about whether everything is fully in order [in animal farming], but giving up one's own lifestyle and meat consumption is a much bigger thing, meaning that you don't change your consumption habits based on [such videos] only. (Academic, Economics.)

In presenting their heuristic, Thomson and colleagues (2015) suggest that a conflict may proceed to a resolution at any stage. However, they also point out that in a strongly contested setting the views of the 
actors can be highly polarised, effectively preventing any resolution from being found. This seems to be exactly the case in the present setting: although the conflict appears to have faded away, the parties remain separated by an antagonistic frontier and no resolution seems to have been reached. The animal activists' identity has, at least for the time being, become fixated as the polar opposite of the identity of the hegemonic bloc:

"They [meat companies] cannot, well, discuss with us, because we question almost everything that there is (...) I feel that their activities are defined by money, or the manufacturing of the animal product and the business, whereas our activity is defined by the questioning of that very logic, which implies that it is difficult [to discuss]." (Activist, Cameraperson B.)

"Their goal, I think it is so far-off from our normal society [...] In my view there is no point to engage in a discussion with that section [activists] as long as their ultimate goal is to stop meat eating." (Representative 2, Farmer interest group.)

"As long as their goal is to stop meat eating, any discussion with them is not going to help. Their aim is so far-out from where we live. [...] And their means for achieving the goal is torturing animals." (Representative 1 from M inistry of Agriculture and Forestry.)

Thomson and colleagues (2015) describe escalation as an alternative direction for a conflict to proceed in. Escalating a conflict would imply for instance that the claimants sought to delegitimize powerful political and regulatory authorities through strong claims questioning the latter's authority or institutional position. Moreover, escalation could also entail broadening the topic area by merging it with another arena. In this way the focus of the conflict could shift from the original topic to the dominant governing regime. In the present case however no such opening up took place: although the focal point fluctuated between animal rights and animal welfare, it never broadened substantially to other social areas or questions beyond animal production. On the contrary, while the counter-accountants aimed at questioning the institution of animal production more broadly, the public discussion narrowed down to possible refinements in the prevailing structures.

By rearticulating animal production and related concepts with the new information and alternative perspective provided by the counter accounts, the counter-accountants sought to rearticulate the nodal point of animal production and the associated societal discourse. Overall, however, this radical political demand of transforming the dominant operating logic of society, large-scale animal production and consumption, cannot be seen to have been very successful. From an animal rights position the developments within the industry are merely incremental in the sense that the fundamental operating logic of the meat industry is not under question, and most of the changes can be argued to have focused on improving animal welfare within the prevailing governance structure. Our interviewees suggest that as a result of the release of the videos individual producers' contracts with food companies have been terminated, regulators have received more resources to inspect farms, and the pig industry has been prompted to develop and test welfare indicators. At the same time, however, it is also evident that the formerly fairly sedimented discourse around animal production has shifted to an extent. In the realm of politics, for example, there have been vocal demands for welfare improvements such as the abolishment of sow cages and other infrastructural changes. Likewise, whereas previously in Finland there was only limited discussion of the animals or farms behind the meat products, we can now witness a proliferation of quality labels and traceability features. 
"The industry is very much of the opinion that [the filmings] have been beneficial, especially for the pigs but also for the business. Of course they [the meat firms] don't say thank you, but they have openly admitted that a lot has happened because of the films." (Academic, animal welfare.)

"There is always so much whining about the videos, that they just kick the innocent and so forth, but they do bring some good things as well. They lead to societal discussion and that is one of the things that has pushed [the industry] forward." (Corporate representative, meat industry.)

Despite these developments, we could argue that although the counter-accountants pursued their counterhegemonic project systematically and indefatigably, they were less successful in linking these efforts to the political work necessary to engender marked changes in the articulation of animal production or the animals' identity. This could be because of mutual suspicions between the activists' and the dominant bloc, as evinced by the preceding interview quotes. For instance, when the implications of the counter accounts were formally discussed in political committees, memos of these hearings indicate that the activists who professed to having participated in the filming or representatives of the animal rights NGO were not invited to take part. Instead, governing actors consulted representatives from conventional animal protection NGOs that promote incremental rather than radical change, and are hence located on the same side of the antagonistic frontier as the dominant regime. Nonetheless, as is often the case with long-term social changes and campaigns, it is complicated to evaluate whether the counter accounts studied here could be considered a success. We will return to this point in more general terms in our discussion below.

\section{Concluding discussion}

Counter accounts have been suggested as an alternative to enhance information flow to various constituencies and thereby facilitate steps towards a more sustainable society (Cooper et al., 2005; Gallhofer et al., 2015, Spence, 2009). Despite emerging interest in this topic, there is still a paucity of studies on counter accounts in action, focusing especially on the role of the activists and their strategic use of the accounts. Towards this end, we presented a longitudinal case study that explored the use of counter accounts during an episode taking place in Finland, where some animal rights activists have actively campaigned against industrial meat and dairy production. With this study we provide two contributions to the accounting literature. First, we examine the conditions under which counter accounts could engender social change. Second, and more particularly, we illustrate how societal perceptions of counter-accountants and their strategies are associated with the transformative potential of counter-accounts. Thereby, we provide further insights to the discussions regarding the societal relevance of counter accounts (e.g. Thomson et al., 2015; Gray et al., 2014, Apostol, 2015) as well as the role and possibilities of accounting and accountability in pluralistic societies (Brown et al., 2015). In what follows we elaborate on our contributions by discussing them through several intertwining themes, including the constitution of the counter accountants' identity, the significance of confrontation and polarization, the necessity of an articulated political vision, the ethical issues related to counter accounts, as well as the evaluation of success when it comes to counter accounts achieving their aims.

As Brown and Dillard (2013a) point out, the articulation of a viable and comprehensive political vision is an important element in attempts to achieve social change. In this case, the counter-accountants' articulated political vision of the alternative and the changes required remained vague. The websites hosting the video clips included sections entitled "what you can do", which provided some suggestions for those individuals 
interested of animal rights. There was however very little information about any broader societal or political vision that the activists were seeking to advance. Instead, it appears that the counter-accountants focused on highlighting that the status quo the dominant political regime is promoting is inherently cruel. Did the animal rights activists limit the potential of their campaign by not being able to articulate a clear political vision? The counter accounts were produced to provide information about the status quo, that is, how meat production is organized in contemporary society. They provided a striking a contrast to corporate advertisements as well as annual and CSR reports, which arguably have avoided describing how animal production looks like. It appears however that the activists placed considerable trust on the broad ranks of citizens, whom they assumed would be mobilized by the alternative information into changing their dietary habits.

Based on our research material, we would however argue that such a decision to trust the citizens did not necessarily further the activists' cause. Although the activists rearticulated the nodal point of animal production with their counter accounts, their articulation left several questions unanswered, including those concerning their proposed alternative. At the same time, in answering the activists' contestation the dominant bloc provided the public with tangible actions that would help to enhance animal welfare and thereby reconstitute the meaning of animal production. The measures included requiring bigger living spaces for the farm animals, regular and effective state regulated veterinary inspections as well as the proliferation of self-regulated industry quality labels. Citizens were clearly interested in animal welfare, but the dominant bloc offered them an achievable solution: traceability of the origins of meat products to individual farms, quality labels, and narratives from the farms. One could thus choose and affect the prevailing practices without making any major commitments or changes in one's own lifestyle. In contrast, the solutions proposed by the counter-accountants appeared either vague or radical and beyond means.

As for the various social groups, the respective identities of the activists and the dominant bloc have emerged as polar opposites and the groups consider it rather impossible to ever reach an agreement in this matter. $A$ clear division to two irreconcilable camps separated by an antagonistic frontier is evident (see Laclau, 2005). During the process and in our interviews representatives of the dominant regime have sought to undermine the activists' rearticulation, trying to represent the counter-accountants as militant, incompetent, and subjective. Activists in turn perceive the meat industry representatives as being cruel capitalists driven only by profit considerations, with whom it makes no sense to talk. In other words, the relationship between the two groups can be characterized as antagonistic as opposed to agonistic (Brown and Dillard, 2013b; M ouffe, 2013).

Drawing on Brown and colleagues (2015), it can however also be maintained that polarization, temporary antagonisms and political frontiers are necessary elements of a pluralistic society (see Brown and Dillard, 2013a). Laclau (1996) likewise argues that confrontation is an inevitable part of democracy. He maintains that reaching a fully reconciled society is impossible, since the "chasm between the universal and the particular is unbridgeable" (Laclau, 1996, p. 26): the values, demands and requests of various particular groups will necessarily clash, and as any universal is just one of the particulars which has gained a dominant position at some moment, confrontation cannot be avoided. It can also be argued that the consensus-based approach, in which the alternative views of various social groups are (ostensibly) listened to and taken into account, risks the 'heretic' views becoming captured by the more established groups with power, as discussed by Archel and colleagues (2011) in regard to corporate stakeholder engagement processes. In this case it is obvious that mere regulatory inspections would not have advanced the activists' ultimate cause, the subsequent abolishment of animal products and production. Using the terminology presented by 
Thomson et al. (2015), resorting to mere systematic external accounts as called for by the establishment would not simultaneously have questioned the broader system and the institutionalized social, economic and political structures around meat production and consumption. Initiating the conflict through the use of partisan external accounts made it possible to stem a broader debate, within which the prevailing governance structures could also be highlighted and questioned (O'Sullivan and O'Dwyer, 2009). Or, in Laclau's (1996) terms, with the counter accounts the activists attempted to open the closure and rearticulate the nodal point of animal production, thereby also seeking to highlight that this seemingly universal and taken for granted articulation is another particular, a result of a particular social and economic constellation, in which particular values and worldviews are considered primary. As discussed above, despite these efforts the public debate did not eventually focus on animal rights and animal production per se, but took a welfarist spin where the main point was improving the conditions within which animals were kept in the production facilities.

In the aftermath of the release of the video material, in the public discussion it was asked whether such polarization was necessary and could not the activists have advanced their aims with some other, less confrontational means. Brown and colleagues (2015, p. 635) mention three broad categories for the classification of those seeking to think or act otherwise: "Acting in accord with the rules; raising a problem through established procedures and institutions with a view to changing it; and confronting governance to further social change." Elaborating on the third category further, Brown and colleagues (2015) discuss how bottom up strategies of struggle, such as direct action, revolt and decolonization, can be used to confront or escape relations of domination. In this case it is rather evident that the first two alternatives had already been attempted with limited success. The first category, acting according to the prevailing social logic, was unthinkable for the animal rights activists in the long run, since the dominant governing regime was founded on mass production and consumption of animals. The second category could have meant for instance producing systematic external accounts (Thomson et al., 2015) about animal production and thereafter leaving it to the authorities to investigate the cases further and engage in necessary governing actions. Such an approach would have required that the activists trusted the authorities to advance their requirements, which clearly was not the case. The counter accounts employed fall into the third category as they sought to contest and transform the dominant regime (see Thomson et al., 2015) by making alternatives visible. In this case, however, the established institutions have transformed only incrementally, although some small but nonetheless tangible changes have taken place also within the more powerful social groups, such as the government authorities and the meat industry.

Moreover, Brown and colleagues (2015) suggest that in seeking to achieve social transformation it may be necessary to engage in the building of alliances, within which different groups can overcome their differences or partly varying interests to promote and advance a common cause in a chain of equivalence (Laclau and M ouffe, 1985; Jørgensen and Phillips, 2002; Spence and Shenkin, 2008; M ouffe, 2013). In the case at hand, we suggest that one of the reasons why the counter accounts initially lead to only limited tangible consequences was that the counter-accountants did not succeed in building chains of equivalence across different spheres of society. Instead, partly due to the counter-accountants' earlier reputation and the decision to work anonymously, the dominant social groups were in the public debate able to form their own chain of equivalence by constituting their identity through radical negativity, thereby undermining the counter-accountants' attempt to rearticulate the nodal point of animal production. As the conflict proceeded, the activists sought to overcome this by both coming out to publicity as individuals and by using targeted counter accounts to constitute links between prominent figures of the dominant groups and the suffering production animals. We would argue however that these efforts were of limited success as they did not result in the displacement of the antagonistic frontier drawn by the hegemonic bloc. M oving on to a more 
theoretical level, based on our analysis we propose that in seeking to enhance the transformative potential of counter accounts the counter-accountants also need take care of how their own identity becomes represented by the hegemonic bloc. Whereas in other recent studies (Apostol, 2015; Brennan and M erklDavies, 2014; Thomson et al., 2015) counter-accountants can be said to have been perceived as being a part of or acting on behalf of some weaker social groups, in our case the activists were represented at least partly as villains, who were prepared to use any means to advance their personal ideology and particular values without listening to or respecting the needs of other social groups. Accordingly, we maintain that scholars seeking to advance accounting literature regarding the role of counter accounts in society would benefit from considering the relevance of the counter-accountants' identity, and societal perceptions thereof, in their research.

Another intriguing angle to the counter accounts presented in this case relates to ethics. As mentioned in the front end of the paper, in producing the video material the counter-accountants took advantage of the low security levels characteristic of the Finnish countryside. Over a couple of years the counter-accountants were able to visit a substantial number of farms in different parts of the country and enter the unlocked animal shelters and production facilities. The activists have highlighted that they never caused any harm or damaged any property in producing the counter accounts. As mentioned above, however, various interviewees claimed that such intrusions caused stress to the animals, risked spreading animal diseases, as well as caused significant mental health issues to individual farmers. Here, we encounter a classic ethical dilemma: what kind of sacrifices, risks or negative effects are acceptable when fighting for a greater cause? The public opinion in Finland was clearly on the side that the counter-accountants crossed the line by entering private property. Our case is hence somewhat different from those in which counter accounts have largely been formed from publicly available material (e.g. Apostol, 2015; Thomson et al., 2015). It is worth pointing out that we do not intend to judge the counter-accountants from an ethical perspective, but suggest that further research on the ethical aspects of counter accounts is clearly warranted.

It is an often asked question whether a particular activist campaign, or any counter-hegemonic rearticulation, proved successful in regard to achieving its aims. As highlighted by Brennan \& Merkl-Davies (2014), Greenpeace can be perceived to have been successful with its "Dirty Laundry" campaign against international clothing companies, as those organizations had to make changes to their practices as a result of the campaign. Likewise, Thomson and colleagues (2015) posit that the long-term ASH campaign against tobacco production and consumption was "influential in bringing about significant transformation of what ASH considered to be undesirable activities" (p. 838). In the present case concerning animal production, the evaluation of success is considerably more complicated. It seems rather clear that very few, if any, major effects have occurred as an immediate consequence of the campaign. Simultaneously, however, and also discussed in our findings above, tangible changes have taken place in the Finnish society in the aftermath of the videos. The percentage of vegetarians amongst the younger generations has risen considerably in recent years and vegetarian diets feature as a standard option in the press, whereas the meat industry highlights the traceability of their products and the importance of animal welfare in their ethical principles. It is however well-nigh impossible for us to prove the existence of a clear causal connection between the counter accounts and the societal changes - and it may well be that success lies in the eye of the beholder: in this case the counter-accountants perceive their campaign to have been a great success, whereas many representatives of the dominant bloc maintain that the effects were minimal. Given our reading of Laclau and M ouffe (1985), we would be wary of judging a counter account as a clear-cut success or failure, since such categories are social constructions in a given setting (see Fraser, 2012). 
As a short epilogue, it is worth pointing out that recently the public discussion in Finland around animal rights and industrial meat production and consumption has taken a new twist. Several notable public figures, celebrities and politicians have been talking about farming conditions and animal welfare. Vegetarianism is being discussed and indeed promoted on mainstream fora: for instance, in July 2016 the editorial of the leading Finnish daily Helsingin Sanomat declared that "vegetarianism should not be considered a special diet" (H.S. 11.7.2016), while in January 2017 in a highly regarded business magazine Kauppalehti Optio it was noted that "Being a vegetarian no longer begs an explanation; on the contrary, reasons are required if one eats meat" (Optio, 19.1.2017). M oreover, commitment to action has also been easier via achievable public events and goals. The Vegan Challenge, a social media campaign encouraging people to try veganism for one month, has been supported and promoted by celebrities and politicians, who cannot be dismissed as extreme radicals. The joining of forces by the activists and popular public figures has arguably lowered the bar for a great number of people to try plant-based diets. It may well be that, as opposed to animal production, the term vegetarianism will act as an empty signifier with the ability to unite disparate groups' interests into a more universal discourse. We maintain that this further underscores how the formation of chains of equivalence should also be taken into account in analysing the transformative potential of counter accounts (see Mouffe, 2013).

\section{References:}

ActionAid (2010). Calling time: Why SABM iller should stop dodging taxes in Africa.

Anderson, P. (2016), "The Heirs of Gramsci”, New Left Review, 100, p. 71-97.

Angermuller, J., M aingueneau, D. \& Wodak, R. (2014), The Discourse Studies Reader: Main currents in theory and analysis. John Benjamin's publishing company, Amsterdam.

Apostol, O.M. (2015), "A project for Romania? The role of the civil society's counter accounts in facilitating democratic change in society", Accounting, Auditing \& Accountability Journal, Vol. 28 No. 2, pp. 210 - 241.

Archel, P., Husillos, J., \& Spence, C. (2011). The institutionalisation of unaccountability: Loading the dice of Corporate Social Responsibility discourse. Accounting, Organizations and Society 36, 327-343.

Bebbington, J. \& Larrinaga, C. (2014), "Accounting and sustainable development: An exploration", Accounting, Organizations and Society, Vol. 39 No. 6, pp. 395-413.

Bebbington, J., Unerman, J. \& O'Dwyer, B. (2014), Sustainability Accounting and Accountability, Abingdon, Routledge.

Beck, U. \& Willms, J. (2004), Conversations with Ulrich Beck, Polity Press.

Boiral, O. (2013), "Sustainability reports as simulacra? An external account of A and A+ GRI reports", Accounting, Auditing and Accountability Journal, Vol. 26 No. 7, pp. 1036-1071.

Boltanski, L. (1999). Distant Suffering: M edia, M orality and Politics.

Brennan, N.M . \& M erkl-Davies, D.M . (2014), "Rhetoric and argument in social and environmental reporting: the Dirty Laundry case", Accounting, Auditing \& Accountability Journal, Vol. 27 No. 4, pp. 602 - 633. 
Brown, J. (2009), "Democracy, sustainability and dialogic accounting technologies: Taking pluralism seriously", Critical Perspectives on Accounting, Vol. 20, pp. 313-342.

Brown, J. \& Dillard, J. (2015). Dialogical accountings for stakeholders: On opening up and closing down participatory governance. Journal of Management Studies, 52(7), 961-985.

Brown, J., \& Dillard, J. (2013a). Agonizing over engagement: SEA and the death of environmentalism debates. Critical Perspectives on Accounting, 24(1), 1-18.

Brown, J., \& Dillard, J. (2013b). Critical accounting and communicative action: on the limits of consensual deliberation. Critical Perspectives on Accounting, 24 (3), 176-190.

Brown, J., Dillard, J., \& Hopper, T. (2015). Accounting, accountants, and accountability regimes in pluralistic societies: taking multiple perspectives seriously. Accounting, Auditing and Accountability Journal, 28(5), 626-650.

Butler, J., Laclau, E. and Zizek, S. (Eds.) (2000). Contingency, Hegemony, Universality: Contemporary Dialogues of the Left. Verso, London.

Cho C.H., Laine M., Roberts R.W. and Rodrigue M. (2015), "Organized hypocrisy, organizational façades, and sustainability reporting", Accounting, Organizations and Society, Vol. 40 No. 1, pp. 78-94.

Chouliaraki, L. (2006). Towards an analytics of mediation. Critical Discourse Studies, 3(2), 153-178.

Cooper, C., Taylor, P., Smith, N., \& Catchpowle, L. (2005), "A discussion of the political potential of social accounting", Critical Perspectives on Accounting, Vol. 16, pp. 951-974.

Dey, C. (2007), "Developing silent and shadow accounts", in: Unerman, J., Bebbington, J. \& O'Dwyer, B. Sustainability Accounting and Accountability, Oxon, Routledge, pp. 30-326.

Dey C., Russell, S., \& Thomson, I. (2011), "Exploring the potential of shadow accounts in problematising institutional conduct", in Osbourne, S., \& Ball, A. (Eds.) Social accounting and public management: Accountability for the common good, Routledge, Abingdon, pp. 64-75.

Dillard, J., \& Brown, J. (2012). Agonistic pluralism and imagining CSEAR into the future. Social and Environmental Accountability Journal, 32(1), 3-16.

Dillard, J ., \& Brown, J. (2015). Broadening out and opening up: antagonistic attitude toward progressive social accounting. Sustainability Accounting, M anagement and Policy Journal, 9(2), 243-266.

Francione, G. (2010), Rain without thunder: The ideology of the animal rights movement, Temple University Press.

Fraser, M . (2012), "“Fleshing out" an engagement with a social accounting technology", Accounting, Auditing $\&$ Accountability Journal, Vol. 25 No 3 pp. 508-534.

Gallhofer, S., Haslam, J., M onk, E., \& Roberts, C. (2006), "The emancipatory potential of online reporting: The case of counter accounting", Accounting, Auditing and Accountability Journal, Vol. 19 No. 5, pp. 681-718. 
Gallhofer, S., Haslam, J., and Yonekura, A. (2015), "Accounting as differentiated universal for emancipatory praxis: accounting delineation and mobilisation for emancipation(s) recognising democracy and difference", Accounting, Auditing and Accountability Journal, Vol. 28 No. 5, pp. 846-874.

Georgakopoulos, G. \& Thomson, I. (2008), "Social reporting, engagements, controversies and conflict in Scottish salmon farming", Accounting, Auditing and Accountability Journal, Vol. 21 No. 8, pp. 1116-1143.

Glynos, J. \& Howarth, D. (2007), Logics of critical explanation in social and political theory. Routledge, Oxon.

Gray, R. (2002), "The social accounting project and Accounting, Organizations and Society: Privileging engagement, imagining new accountings and pragmatism over critique?", Accounting, Organizations and Society, Vol. 27 No. 7, pp. 687-708.

Gray, R., Brennan, A. \& Malpas, J. (2014), "New accounts: Towards a reframing of social accounting" Accounting Forum, Vol. 38 No. 4, pp. 258-273.

Harte, G. \& Owen, D. (1987), "Fighting de-industrialisation: The role of local government social audits", Accounting, Organizations and Society, Vol. 12 No. 2, pp. 123-141.

Hines, R. D. (1988), "Financial accounting: in communicating reality, we construct reality", Accounting, Organizations and Society, Vol. 13 No. 3, pp. 251-261.

Howarth, D. \& Stavrakakis, Y. (2000). "Introducing Discourse Theory and Political Analysis", in Howarth, D., Norval, A. \& Stavrakakis, Y. (eds), Discourse Theory and Political Analysis: Identities, Hegemonies and Social Change, Manchester UP, M anchester, pp. 1-37.

Jørgensen, M ., \& Phillips, L. (2002). Discourse analysis as theory and method. London: Sage.

Kneip, V. (2013), "Protest campaigns and corporations: Cooperative conflicts?", Journal of business ethics, Vol. 118 No. 1, pp. 189-202.

Konttinen, E. \& Peltokoski, J. (2004), Ympäristöprotestin neljäs aalto. Eläinoikeusliike ja uuden polven ympäristöradikalismi 1990-Iuvulla. [The Fourth Wave of Environmental Protest. The Animal Rights Movement and the New Generation of Environmental Radicalism in the 1990s], Jyväskylä, Minerva Publications Ltd.

Laclau, E. (2005), On Populist Reason. Verso, London.

Laclau, E. (2001), "Democracy and the question of power", Constellations, Vol. 8 No. 1, pp. 3-14.

Laclau, E. (1996), Emancipation(s). Verso, London.

Laclau, E. and Mouffe, C. (2001/1985), Hegemony and Socialist Strategy: Towards a Radical Democratic Politics, Second edition. Verso, London.

Lehman, C., Annisette, M . \& Agyemang, G. (2016), "Immigration and neoliberalism: three cases and counter accounts", Accounting, Auditing \& Accountability Journal, Vol. 29 No. 1, pp. 43-79.

Luque-Vilchez, M. \& Larrinaga, C. (2016), “Reporting models do not translate well: Failiing to regulate CSR reporting in Spain", Social and Environmental Accountability Journal, Vol. 36 No. 1, pp. 56-75. 
Marchant, O. (2004), "Politics and the Ontological Difference. On the 'strictly philosophical 'in Laclau's work". In Critchley, S. and M archant, O. (eds), Laclau: A critical reader, pp. 54-72. Routledge, New York.

M cM ichael, J., Powles, C., \& Butler, R. (2007), "Food, livestock production, energy, climate change, and health", Lancet, Vol. 370, pp. 1253-1263.

M ilne, M . . . \& Gray, R. (2013), "W(h)ither ecology? The triple bottom line, the Global Reporting Initiative and corporate sustainability reporting", Journal of Business Ethics, Vol. 118 No. 1, pp. 13-29.

Milne, M.J., Tregidga, H. and Walton, S. (2009), "Words not actions! The ideological role of sustainable development reporting", Accounting, Auditing and Accountability Journal, Vol. 22 No. 8, 1211-1257.

M ouffe, C. (2013), Agonistics: Thinking the World Politically, London, Verso Books.

O'Sullivan, N. and O'Dwyer, B. (2009), "Stakeholder perspectives on a financial sector legitimation process: the case of NGOs and the equator principles", Accounting, Auditing \& Accountability Journal, Vol. 22 No. 4, pp. 553-587.

Orlich, M. J., Singh, P. N., Sabaté, J., Jaceldo-Siegl, K., Fan, J., Knutsen, S., Beeson, W. L., and Fraser, G. E. (2013), "Vegetarian dietary patterns and mortality in adventist health study 2", JAM A Internal M edicine, DOI 10.1001/jamainternmed.2013.6473

Pluhar, E.B. (2010), "Meat and morality: alternatives to factory farming", Journal of Agricultural and Environmental Ethics, Vol. 23, pp. 455-468.

Power, M. (2004), The Risk Management of Everything: Rethinking the Politics of Uncertainty, London, Demos.

Regan, T. (1983), The Case for Animal Rights, Berkeley, University of California Press.

Rockström, J., Steffen, W., Noone, K., Persson, Å ., Chapin, F., Lambin, E., et al. (2009), "A safe operating space for humanity", Nature, Vol. 461, pp. 472-475.

Rodrigue, M. (2014), "Contrasting realities: corporate environmental disclosure and stakeholder-released information", Accounting, Auditing and Accountability Journal, Vol. 27 No. 1, pp. 119-149.

Rodrigue, M., Cho, C.H. and Laine, M. (2015), "Volume and tone of environmental disclosure: A comparative analysis of a corporation and its stakeholders", Social and Environmental Accountability Journal, Vol. 35 No. 1, pp. 1-16.

Sikka, P. (2006), "The internet and possibilities for counter accountings: some reflections", Accounting, Auditing and Accountability Journal, Vol. 19 No. 5, pp. 759-769.

Singer, P. (1975), Animal Liberation: A New Ethics for Our Treatment of Animals, New York, Random House.

Spence, C. (2009), "Social accounting's emancipatory potential: A Gramscian critique", Critical Perspectives on Accounting, Vol. 20 No. 2, pp. 205-227.

Spence, C. (2007), "Social and environmental reporting and hegemonic discourse", Accounting, Auditing and Accountability Journal, Vol. 20 No. 6, pp. 855-882. 
Spence, C. \& Shenkin, M. (2008), "The rebirth of politics in Bolivia: the role of popular resistance to business", Critical Perspectives on International Business, Vol. 4 No. 4, pp. 344-366.

Steffen, W., Richardson, K.,Rockström, J., Cornell, S.E., Fetzer, I., Bennett, E.M., Biggs, R., Carpenter, S.R., de Vries, W., de Wit, C.A., Folke, C., Gerten, D., Heinke, J., M ace, G.M ., Persson, L.M ., Ramanathan, V., Reyers, B. \& Sörlin, S. (2015), "Planetary Boundaries: Guiding human development on a changing planet", Science, Vol. 347 No. 6223.

Thomson, I., Dey, C. \& Russell, S. (2015), "Activism, arenas and accounts in conflicts over tobacco control", Accounting, Auditing \& Accountability Journal, Vol. 28 No. 5, pp. 809-845.

Tregidga, H., Milne, M . \& Kearins, K. (in press), "Ramping up resistance: Corporate sustainable development and academic research", Business and Society.

Tregidga, H., Milne, M. \& Kearins, K. (2014). (Re)presenting 'sustainable organizations'. Accounting, Organizations and Society, 39(6), 477-494.

Unerman, J. \& Chapman, C. (2014), "Academic contributions to enhancing accounting for sustainable development", Accounting, Organizations and Society, Vol. 39 No. 6, pp. 385-394.

Vinnari, E. and Dillard, J. (2016), "(ANT)agonistics: Pluralistic politicization of, and by, accounting and its technologies. Critical Perspectives on Accounting, Vol. 39, pp. 25-44.

Vinnari, E. and Laine, M. (2017), "The moral mechanism of counter accounts: The case of industrial animal production", Accounting, Organizations and Society, Vol. 57, pp. 1-17.

Vinnari, M . \& Vinnari, E. (2014), "A framework for sustainability transition: The case of plant-based diets", Journal of Agricultural and Environmental Ethics, Vol. 27 No. 3, pp. 369-396.

Vitousek, P., M ooney, H., Lubchenco, J., \& M elillo, J. (1997), "Human domination of Earth's ecosystems", Science, Vol. 277, pp. 494-499.

Wodak, R. \& M eyer, M (2015): M ethods of critical discourse studies. 3rd ed (1 $1^{\text {st }}$ ed / 2001). Sage, London.

Ylönen, M . \& Laine, M (2015). 'For Logistical Reasons Only? A Case Study of Tax Planning and Corporate Social Responsibility Reporting', Critical Perspectives on Accounting, Vol. 33, pp. 5-23. 


\section{CHRONOLOGY OF EVENTS}

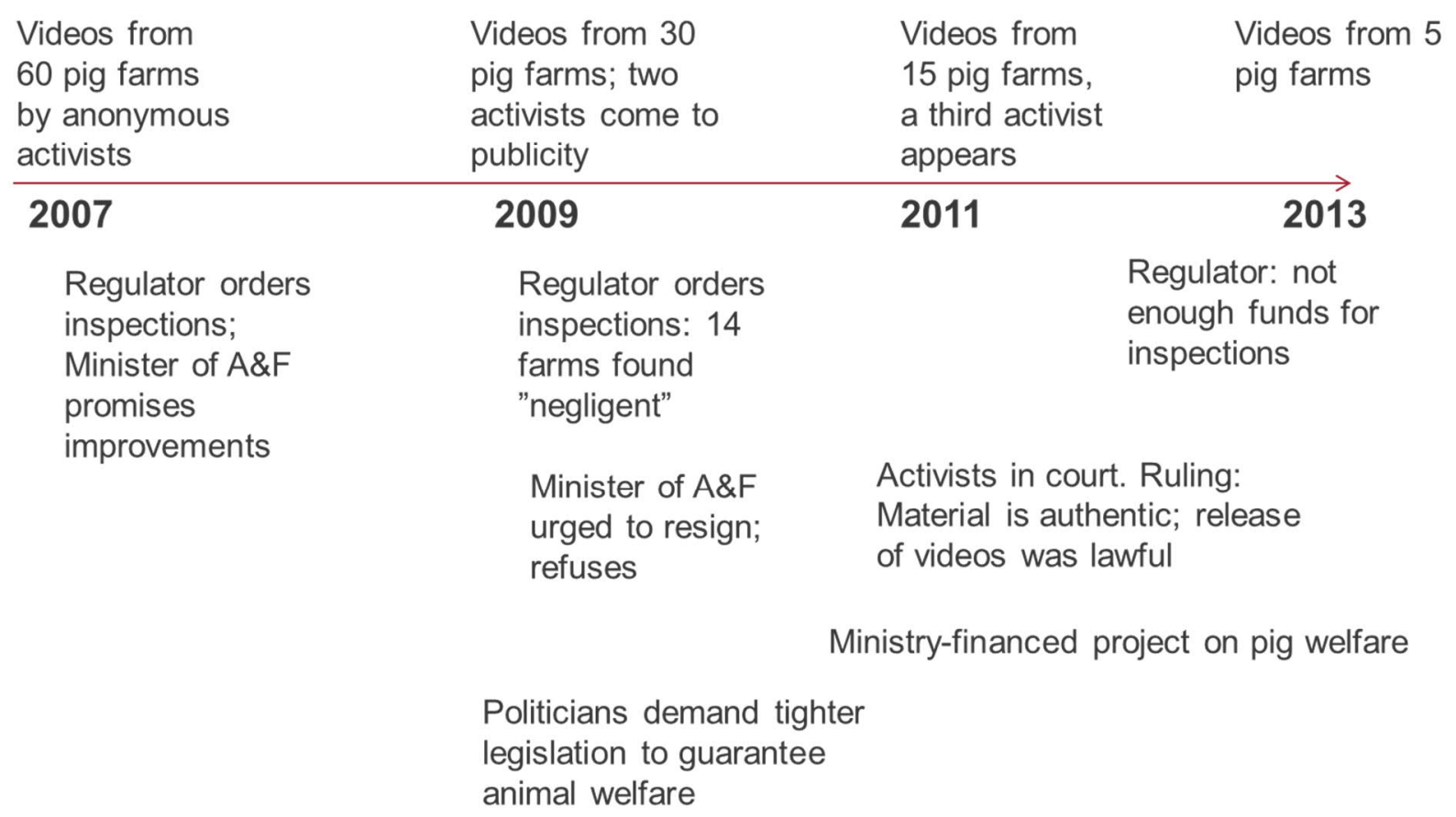

Figure 1. Chronology of events 
APPENDIX 1: The empirical material used in the study:

Details of interviews conducted for the project (December 2013-June 2014)

\begin{tabular}{|l|l|}
\hline Academic/ sociology & $60 \mathrm{~min}$ \\
\hline Academic / economics & $60 \mathrm{~min}$ \\
\hline Academic / animal welfare & $55 \mathrm{~min}$ \\
\hline Corporate representative / meat industry & $45 \mathrm{~min}$ \\
\hline Corporate representative / meat industry & $100 \mathrm{~min}$ \\
\hline Corporate representative / meat industry & $70 \mathrm{~min}$ \\
\hline Corporate representative / retail & $45 \mathrm{~min}$ \\
\hline Corporate representative / retail & $45 \mathrm{~min}$ \\
\hline Farmer interest group & $60 \mathrm{~min}$ \\
\hline Farmer interest group & $65 \mathrm{~min}$ \\
\hline Finnish Farm Animal Welfare Council & $55 \mathrm{~min}$ \\
\hline M eat industry interest group & $50 \mathrm{~min}$ \\
\hline M ember of the European Parliament & $60 \mathrm{~min}$ \\
\hline M ember of the Parliament & $45 \mathrm{~min}$ \\
\hline M inistry of Agriculture and Forestry representative, former M inister & $70 \mathrm{~min}$ \\
\hline M inistry of Agriculture and Forestry representative 2 & $50 \mathrm{~min}$ \\
\hline NGO actor / Vegan Society in Finland & $80 \mathrm{~min}$ \\
\hline NGO actor / animal issue NGO & $65 \mathrm{~min}$ \\
\hline NGO actor / environmental NGO & $60 \mathrm{~min}$ \\
\hline Animal activist, cameraperson A & $50 \mathrm{~min}$ \\
\hline Animal activist, cameraperson B & $60 \mathrm{~min}$ \\
\hline & \\
\hline
\end{tabular}


APPENDIX 2: Interview guide (tentative, adapted for each interviewee)

\section{General themes:}

- Background information on the interviewee, his/her organization, and his/her role in the organization

- What does CSR mean for you?

- To what extent and how you deal with questions of animal welfare at work?

- CSR features prominently on your organization's website. Environmental impacts of animal-based products are mentioned, but ethical dimensions of animal production are not taken up. Why?

- How do you follow up with the aims and accomplishment related to animal welfare?

- What do the different animal welfare measurements and other indicators tell us about animals and animal production?

- How has the public and political discussion on animal production changed over the last ten (twenty) years? How about the attitude on animal activism?

- There is nowadays plenty of talk of the responsibility of the Finnish animal production. To whom and for what are the meat producers in your view responsible?

- The meat industry has recently launched several initiatives concerning the improvement of animal welfare. What do you consider to be the reasons behind these initiatives?

- How well can animal welfare be taken care of through voluntary measures? What is the role of political regulation as opposed to voluntary initiatives and actions?

\section{Activists / NGOs}

- What motivates you? Has this changed over time?

- Why did you engage in the filmings of the farms?

- What are the aims of, first, the animal rights activism in general, and, second, the secret filmings, over the short / long term?

- What kind of a world do you envisage to achieve with the filmings and your actions?

- How do you think such a change can be achieved? Do you believe in changing individuals' value positions or do you look for political regulation on animal production or meat consumption?

- How do you perceive initiatives aiming at improving the animal welfare [in contrast to animal rights?] What about organic agriculture?

- What kind of impacts did you expect the filmings to have? Have these been achieved?

- Has the core message of the videos remained the same after they were given to the public domain?

- Has the public discussion been about the topics you would have liked it to be about?

- Has there been sufficient public discussion, and is it still on-going?

\section{Stakeholder dialogue, polylogics}

- On your website you highlight that you are in an on-going dialogue with NGOs. Could you give examples? [Are animal rights and/or animal protection NGOs included? How?]

- Do you consider animal activists as your stakeholder?

- Has your organization sought to engage in a dialogue with the industry [animal rights/ welfare NGOs or individual activists]? Do you think such a dialogue with the opposing party could be useful?

- What kind of feedback do you usually get on animal-based products?

- What kind of actions have you in recent years conducted on the basis of consumer feedback? 
- Your CSR program is based on a stakeholder questionnaire and an analysis of global megatrends. Did the increasing popularity of vegetarian diets or the themes of animal welfare and animal rights feature here, and if so how?

- What is the role of public discussion in regard to animal rights? Who should take part in it?

- At the moment the legitimacy of animal production seems to be discussed only by the meat industry and the animal activists. Which voices are lacking in this debate? [Who should in your view the part in the discussion concerning animal production?]

\section{The videos: their message and comprehensiveness}

- What have the activists actually filmed? [Animal production in general or industrial factory farming in particular?]

- What is the message of the videos? Has it remained constant over time?

- Do the videos give a comprehensive picture of the animal production? [why?]

- Do the CSR reports and adverts produced by the meat industry give a comprehensive picture of animal production? [why?]

- Does the general public in your view trust more the pictures of animal production provided by the animal activists or the corporations in the industry? [why?]

- Were the secret videos in your view necessary and justified? [What kind of pros and cons you see in the videos?]

\section{The target group and impacts}

- Who were in your view the target group of the videos? Has this remained the same over time?

- What kind of impacts the videos have had?

o on the consumers' trust towards meat products?

- on your organization's operations or strategic decisions?

o on the meat industry and meat production?

- on political and public discussion? 